\title{
Primary follicular lymphoma of the cervix uteri: a review
}

\author{
Aylin Fidan Korcum • Ihsan Karadogan • \\ Gamze Aksu • Ayse Aralasmak • Gulgun Erdogan
}

Received: 2 April 2007 / Accepted: 2 June 2007 / Published online: 22 June 2007

(C) Springer-Verlag 2007

\begin{abstract}
Primary non-Hodgkin's lymphoma of the cervix is a rare disease, of which a subgroup of follicular lymphoma constitutes only $8.5 \%$. There is not an established treatment protocol neither for primary cervical lymphoma nor for its follicular subgroup. We presented a case with Ann Arbor stage IEA (Extra-nodal involvement and absence of weight loss, fever, night sweat) primary follicular lymphoma of the cervix. She was treated with chemotherapy followed by pelvic radiotherapy. Upon relapse with a nodal neck mass, she was treated with rituximab alone. She remained well for 23 months after rituximab. In the 39 months of follow-up, there was no evidence of disease. In the light of our case, we reviewed the reported cases of primary follicular lymphoma of the cervix while discussing their treatment protocols and the cases of primary cervix lymphoma treated with rituximab.
\end{abstract}

Keywords Primary cervix lymphoma $\cdot$ Follicular

Radiotherapy . Chemotherapy

A. F. Korcum $(\bowtie) \cdot$ G. Aksu

Department of Radiation Oncology,

Akdeniz University, School of Medicine,

Antalya 07070, Turkey

e-mail: aylinf@hotmail.com

I. Karadogan

Department of Hematology,

Akdeniz University, School of Medicine,

Antalya 07070, Turkey

A. Aralasmak

Department of Radiology,

Akdeniz University, School of Medicine,

Antalya 07070, Turkey

G. Erdogan

Department of Pathology,

Akdeniz University, School of Medicine,

Antalya 07070, Turkey

\section{Introduction}

Primary non-Hodgkin's lymphoma (NHL) of the cervix is extremely rare. Only $0.5 \%$ of extranodal lymphomas in women are likely to originate in the female genital tract [1, 2]. Until now, more than 130 cases of primary NHL of the cervix have been reported. The most common histological subtype is diffuse large B-cell lymphoma [3]. Only 11 cases with low-grade follicular lymphoma of the cervix were reported comprising $8.5 \%$ of the primary cervix lymphomas [2-9].

In the cervical lymphoma, the median age at presentation is 44 years, ranging from 27 to 80 years [5, 10]. The most frequent complaint is abnormal vaginal bleeding [7]. Fever, night sweats, and weight loss are usually not the features of primary lymphoma of the cervix. Other gynecologic symptoms can occur including pelvic pain, postcoital bleeding, postmenopausal bleeding, and dyspareunia [11-13]. Differential diagnosis of primary cervical lymphomas includes benign inflammatory and malignant disease such as cervical carcinomas, sarcomas, and lymphoma-like lesions [3, 14, 15]. For a definitive diagnosis, a deep cervical biopsy with histopathological evaluations and immunophenotyping are required $[14,15]$. Because such located lymphomas are subepithelial and unless there is ulceration and exfoliation, Papanicolaou smear plays a very insignificant role in the diagnosis of cervical lymphoma [7]. Ann Arbor stage, size, and extent of disease, age, number of extranodal sites, performance status, serum lactate dehydrogenase (LDH) values, and grade of lymphoma are significant prognostic features $[4,6,11,16]$.

Because of the rarity, there is not an established treatment protocol for primary NHL of the cervix. Radiotherapy, chemotherapy, and surgery, either alone or in combination, are the mainstay of treatment $[10-12,17,18]$. Some suggested 
that chemotherapy followed by pelvic radiotherapy apparently is the best option with better survival rate $[6,19]$. Moreover, there is not enough experience on the treatment of primary low-grade follicular lymphoma of the cervix in the literature. Follicular lymphoma is characterized by continuous relapses with shorter response duration and a shorter survival after each relapse [20]. Treatment options include watchful waiting, oral alkylating agents, purine nucleoside analogues, combination chemotherapy, radiotherapy, interferon, and monoclonal antibodies.

Rituximab, which is a monoclonal antibody, is used for treatment of CD20+ lymphomas. Rituximab is also used for treatment of primary NHL of the cervix [21]. In the literature, there are six cases with large B-cell histology. They were treated with chemotherapy $(\mathrm{CT})+$ rituximab as a first-line regimen with promising results $[17,18,22]$. However, there was only one patient with follicular lymphoma of the cervix who received CT + rituximab as a first-line treatment [9].

In this paper, we presented a case with Ann Arbor stage IEA primary follicular NHL of the cervix [23]. She was first treated with chemotherapy followed by pelvic radiotherapy. Upon a nodal relapse in the neck, she was treated only with rituximab. She remained well for 23 months after rituximab. In the light of our case, we reviewed the available reported cases of follicular lymphoma of the cervix while discussing their treatment protocols and the cases of primary cervix NHL treated with rituximab.

\section{Case report}

A 67-year-old postmenopausal woman presented with abnormal vaginal bleeding and back pain for 2 months. Her past medical, gynecologic, and family histories were all unremarkable. At gynecological examination, there was an exophytic tumor arising from the cervix with spread to the parametrium but not to the pelvic sidewalls. Vaginal ultrasound revealed a cervical mass measuring $75 \times 60 \mathrm{~mm}$ in diameter. Computed tomography (CT) and magnetic resonance imaging (MRI) showed diffuse enlargement and enhancement of the cervix. The cervical tumor was classified clinically as a FIGO stage IIB. Papanicolaou smear results were normal. Cervical biopsy demonstrated low-grade follicular NHL according to WHO classification [24].

Systemic examination did not show any other abnormal findings. Physical examination, staging investigations including routine hematology and biochemistry tests, chest radiograph, CT of neck-thorax-abdomen regions, immunoglobulin pattern and electrophoresis, bone marrow aspiration, and biopsy showed no evidence of lymphoma or other disease in other parts of the body. The patient was staged IEA according to the Ann Arbor staging system for extranodal lymphomas [23].
She was treated with three courses of combination chemotherapy including cyclophosphamide, doxorubicin, vincristine, and prednisone (CHOP). After chemotherapy, MRI showed $70 \%$ decrease in the cervical mass. Because she had myelosuppression and particularly granulocytopenia after three cycles of therapy, bone marrow aspiration and biopsy were repeated. There was no involvement of the bone marrow. Subsequently, she was treated with external radiotherapy (ERT) to the whole pelvis with a box technique using $25 \mathrm{MV}$ linear accelerator. A total dose of 4,140 cGy in 23 daily fractions was applied. She tolerated well with no significant side effects. On follow up, she was in good condition. Radiological and clinical assessments including cervical biopsy revealed no evidence of disease, and the patient remained in complete remission.

After 16 months after the initial diagnosis, a relapse of a 4-cm lymphadenopathy in the neck occurred. A biopsy from the lymphadenopathy again reported as low-grade follicular NHL. Further investigations did not reveal any other evidence of recurrence. She was designated as relapse stage I with a continuing complete response at an irradiated site. Because of the bone marrow toxicity that occurred during the previous treatment, the patient being at an old age and refusing the multidrug chemotherapy regimen, eight cycles of rituximab alone were administered with no adverse events. There was a complete remission after rituximab. The patient remains well at 23 months after rituximab. In the 39 months of follow-up, there was no evidence of disease.

\section{Discussion}

Primary cervical NHLs are defined as the lymphomas that localize at the cervix without any myometrial involvement and any evidence of leukemia at the time of diagnosis [4]. Etiology and pathogenesis of primary cervical NHL are unknown, although there might be a possible association be-tween chronic inflammation and lymphomas [25]. CT and MRI are useful in diagnosis and staging, but their specificity is low $[9,13]$. Cervical biopsy and immunophenotyping are necessary to differentiate primary cervical NHL from benign and malignant disease of the cervix [3, 14, 15, 19]. There is no consensus for staging of lymphoma of the cervix. Both FIGO (International Federation of Gynaecology and Obstetrics) and the Ann Arbor staging systems for extranodal lymphoma are used [24]. The natural history of NHL of the cervix varies with histological types. The most common histological subtype is diffuse large B-cell lymphoma $[3,10,19]$. Reviewing the cases reported in the literature, the follicular subgroup comprises only $8.5 \%$ of the primary cervix NHL cases. Other rare B-cell lymphomas in the cervix are marginal zone B-cell lymphoma and mucosaassociated lymphoid tissue lymphoma $[3,19]$. 
Prognosis of extranodal lymphomas is usually poorer than nodal lymphomas because of inaccurate or delayed diagnosis [26]. However, prognosis of primary cervix NHL, if diagnosed at earlier stages, may be excellent compared to other gynecologic malignancies $[9,21]$. In the cervix lymphoma, the stage and grade of the disease are important predictors of survival. In three large series of primary cervix lymphoma, survival was found to be better in stage IE compared to higher stages, but it was statistically significant only in one of them (stage IE, $89 \%$ versus stages IIE and IV, $20 \%)[2,4,6]$. The grade of the disease is statistically important when comparing the survival between low-grade and high-grade diffuse lymphomas $[2,4,6]$. However, the prognostic significance of the different histological types is still unclear [4]. Based on the combined data of studies, the 5 -year survival rate of patients with a follow-up of at least 5 years is approximately $80 \%[4-6,16]$. One study correlated survival with International Index score, which assesses the age of the patient, Ann Arbor stage, number of extranodal sites, performance status, and serum LDH values [6]. Patients with low scores had statistically significant better survival rates than those with high scores.

The management strategy of primary NHL of the cervix is not clear because of rarity of the disease, different histopathological subtypes, and limited experiences. According to several case reports and a few case series, treatment regimens of primary NHL of the cervix include chemotherapy alone, radiotherapy alone, or radiotherapy combined with either chemotherapy or surgery $[4,6,11-19,21,25,27-34]$. In earlier reports, because of high response rate and low morbidity, radiotherapy was used as the first-line treatment for stage IE disease $[2,4,5,28,29]$. From 1960 to $1990,76 \%$ of the cases of stage IE cervical NHL received radiotherapy [5]. Since $1974,63 \%$ of all primary cervix NHL cases were treated with radiotherapy alone or in combination with surgery and/or chemotherapy. Some suggested that the survival rates in the earlier stage of low and intermediate grade cervical lymphomas are excellent with either surgery, chemotherapy, or radiotherapy. To preserve reproductive function in such young patients and/or to prevent the micrometastasis, combination chemotherapy alone was advocated [14-16, 21]. If involved field radiotherapy (IF-XRT) alone is to be applied in young patients, then ovarian transposition to preserve reproductive and gonadal function shall be considered [10].

According to the recent publications of early stage primary cervix NHL, chemotherapy is suggested before the local treatments to prevent the occult disease not detectable by imaging and to improve the treatment results. The CHOP regimen, which is proved to be effective, is generally used [35]. Recent studies suggest that management with combination of chemotherapy and after pelvic radiotherapy apparently is the best option with better survival and a 5year survival rate of up to $100 \%$ in some series of primary
NHL of the cervix $[3,6,10,16,18,19,29,36,37]$. Reviewing the literature, 36 patients received combination treatment of chemotherapy and external radiotherapy, and only two of them died of disease at the second and ninth month after diagnosis (Table 1) $[3,6,9,10,13,16,18,19$, $22,25,27,30-34,36-42]$.

The cervix is a very unusual extranodal region, and only 11 cases with follicular histology were reported in the literature. The most common extranodal locations of follicular lymphomas are the head and neck, skin, and gastrointestinal system. Follicular lymphoma is characterized by a pattern of continuous relapses with shorter response duration and a shorter survival after each relapse [43]. There are various options for treatment including watchful waiting, oral alkylating agents, purine nucleoside analogues, combination chemotherapy, radiotherapy, interferon, monoclonal antibodies, and autologous or allogeneic bone marrow or peripheral stem cell transplantation.

The usual therapy for stage I-II low-grade follicular NHL patients is a moderate dose IF-XRT [44, 45]. Many large series reported similar results with $28-53 \%$ of patients free from recurrence, overall survival rates of $60-70 \%$ after ten or more years, and a low risk of recurrence beyond this time [44, 46, 47]. Relapses usually occur at unirradiated sites and within the first 5 years. The dominant sites of failure are systemic, attributable likely to occult disease, which is left untreated [46, 47].

An alternative approach to improve the efficacy of IFXRT is the addition of chemotherapy. The CHOP regimen is also used as the treatment regimen for low-grade lymphomas $[35,48]$. The retrospective studies suggested possible benefit from the use of combined modality therapy in these patients $[49,50]$. However, randomized studies regarding effectiveness of chemotherapy at the early stages of the low-grade follicular NHL did not show a statistically significant result because of the inadequate number of patients and inability to follow up for a long time [45, 5153]. Comparing the series of radiation alone treatment with the long-term results of combined modality treatment from MD Anderson, the combined modality approach appears to provide a $20-30 \%$ improvement in the likelihood of remaining free of recurrent disease 10 years after treatment [54]. The 10-year survival after relapse was $46 \%$. This potentially improved outcome was achieved without apparent long-term toxicity. However, studies evaluating the treatment results and features of the rarely seen follicular subgroup of extranodal lymphoma are insufficient. Therefore, it is not clear how to treat rarely seen extranodal follicular lymphomas in the literature.

Until now, there are 11 reported cases with primary lowgrade follicular lymphoma of the cervix [2-9]. Patients were treated with radiotherapy, chemotherapy, and surgery in varying combinations (Table 2). Seven of them are in 
Table 1 Primary cervix lymphoma cases treated with chemoradiotherapy in the literature

\begin{tabular}{|c|c|c|c|c|c|c|c|}
\hline References & Number & Age & $\begin{array}{l}\text { Ann Arbor } \\
\text { stage }\end{array}$ & NHL subtype & Treatment & $\begin{array}{l}\text { Follow-up } \\
\text { (month) }\end{array}$ & Response \\
\hline $\begin{array}{l}\text { Cantu de Leon et al. } \\
\text { [42] }\end{array}$ & 1 & 56 & IIE & DLBC & CT(CHOP)-P ERT & 6 & $\mathrm{CR}$ \\
\hline Hariprasad et al. [10] & 2 & 47 & IE & DLBC & CT(CHOP)-P ERT & 13 & $\mathrm{CR}$ \\
\hline Chan et al. [37] & 3 & 40 & IVEA & $\mathrm{G}$ & CT(CHOP)-P ERT & 120 & NED \\
\hline \multirow[t]{2}{*}{ Heredia et al. [34] } & 4 & 32 & IEA & Diffuse mix B cell & CT(CHOP)-P ERT & 61 & NED \\
\hline & 5 & 31 & IIEA & Diffuse mix B cell & CT(CHOP)-S-ERT & 15 & NED \\
\hline Kendrick et al. [22] & 6 & 47 & IIE & Int grade LBC & $\begin{array}{l}\text { CT(CHOP-RIT)-P } \\
\text { ERT }\end{array}$ & 16 & NED \\
\hline Thyagarajan et al. [13] & 7 & 41 & IVE & High grade B cell & CT-P ERT & 7 & NED \\
\hline Kahlifa et al. [41] & 8 & 32 & IEA & DLBC & $\begin{array}{l}\text { CT(CHOP-RIT)-P } \\
\text { ERT }\end{array}$ & 10 & $\mathrm{CR}$ \\
\hline Bode et al. [9] & 9 & 46 & IEA & FL & $\begin{array}{l}\text { CT(CEOP-RIT)-P } \\
\text { ERT }\end{array}$ & 10 & $\mathrm{CR}$ \\
\hline Yokoyama et al. [31] & 10 & 55 & IIEA & G & $\begin{array}{l}\text { CT(CEOP-RIT)-P } \\
\text { ERT }\end{array}$ & 12 & NED \\
\hline Vang et al. [19] & 11 & 57 & IIEA & DLBC & CT-P ERT & 120 & NED \\
\hline Tunca et al. [30] & 12 & 22 & IEA & G & CT-P ERT & 30 & NED \\
\hline Mansouri et al. [40] & 14 & 34 & IEA & I & CT-P ERT & 48 & $\mathrm{CR}$ \\
\hline Castaldo et al. [38] & 15 & 33 & & DSC & S-CT-ERT & 9 & DOD \\
\hline Strang et al. [32] & 16 & 77 & IE & Centroblastik & CT(COP)-P ERT & 36 & NED \\
\hline \multirow[t]{2}{*}{ Khoury et al. [33] } & 17 & 37 & IE & DLC & CT(CHOP)-P ERT & 96 & NED \\
\hline & 18 & 46 & & & CT(COP)-P ERT & 102 & NED \\
\hline \multirow{2}{*}{$\begin{array}{l}\text { Makarewicz and } \\
\text { Kuzminska [27] }\end{array}$} & 19 & 37 & IEA & $\mathrm{DBC} C \mathrm{C}$ & CT(COP)-P ERT & 96 & NED \\
\hline & 20 & 65 & IEA & $\begin{array}{l}\text { B-cell } \\
\text { lymphoblastic }\end{array}$ & CT(COP)-P ERT & 36 & NED \\
\hline \multirow[t]{6}{*}{ Stroh et al. [6] } & 21 & 53 & IEA & $\mathrm{G}$ & CT(CHOPB)-P ERT & 172.8 & NED \\
\hline & 22 & 64 & IEA & & CT(CHOPB)-P ERT & 164.4 & NED \\
\hline & 23 & 39 & IIEA & & CT(CHOPB)-P ERT & 141.6 & NED \\
\hline & 24 & 35 & IIIEB & & CT(CHOPB)-P ERT & 117 & NED \\
\hline & 25 & 66 & IEA & & CT(CHOP)-P ERT & 60 & NED \\
\hline & 26 & 67 & IEA & & CT(ASHAP)-P ERT & 18 & NED \\
\hline $\begin{array}{l}\text { Papadopoulos et al. } \\
\text { [39] }\end{array}$ & 27 & & IEB & $\mathrm{H}$ & S-CT(CHOP)-PERT & 48 & NED \\
\hline Aozasa et al. [25] & 28 & 71 & NA & DLBC & CT-P ERT & 2 & DOD \\
\hline \multirow[t]{6}{*}{ Vang et al. [3] } & 29 & 39 & IE & $\mathrm{G}$ & CT-P ERT & 7 & NED \\
\hline & 30 & 57 & IIEA & $\mathrm{G}$ & CT-P ERT & 120 & NED \\
\hline & 31 & 57 & IIEA & G & CT-P ERT & 60 & NED \\
\hline & 32 & 52 & IEA & DLBC & CT-P ERT & 12 & NED \\
\hline & 33 & 61 & IIEA & FL & S-CT-ERT & 72 & NED \\
\hline & 34 & 67 & IEA & DLBC & CT-P ERT & 60 & NED \\
\hline Chandy et al. [36] & 35 & 50 & IEA & $\mathrm{H}$ & CT-P ERT & 24 & NED \\
\hline Cohn et al. [18] & 36 & 22 & IE & DLBC & CT(CHOP)-P ERT & 14 & NED \\
\hline Present & 37 & 67 & IE & FL & CT(CHOP)-P ERT & 39 & NED \\
\hline
\end{tabular}

$C T$ Chemotherapy, $P$ ERT pelvic external radiotherapy, $S$ surgery, $R I T$ rituximab, $F L$ follicular lymphoma, $D L B C$ diffuse large B cell, $D L C$ diffuse large cell, Int grade $L B C$ intermediate grade large B cell, $G$ malignant lymphoma diffuse, $H$ malignant lymphoma large cell, $I$ malignant lymphoma lymphoblastic, $C C$ centroblastic centrocytic, $N E D$ no evidence of disease, $D O D$ died of disease, $C R$ complete remission

Stage I, two in Stage II, one in Stage III, and one in Stage IV. To $6(54.5 \%)$ out of 11 follicular lymphoma patients, external radiotherapy was applied. While radiotherapy was used in three patients after surgery, in one patient combined with chemotherapy, and in two other combined postoperatively with chemotherapy; surgery alone was done for three $(27 \%)$ patients. In eight $(73 \%)$ patients, the diagnosis was done by surgery. While one $(9 \%)$ patient was under wait and watch, one (9\%) received chemotherapy alone. Total dose of radiotherapy varied between 30 and 45 Gy. Follow-up time ranged from 4 months to 14 years. Even in our case, there was an issue of nodal relapse in the 16th 
Table 2 Primary low grade follicular lymphoma of the cervix from the literature

\begin{tabular}{|c|c|c|c|c|c|c|}
\hline Author (year) & Number & Age & $\begin{array}{l}\text { Ann Arbor } \\
\text { stage }\end{array}$ & $\begin{array}{l}\text { First-line } \\
\text { treatment }\end{array}$ & $\begin{array}{l}\text { Treatment of } \\
\text { relapse }\end{array}$ & Survival \\
\hline Charlton I (1974) [2] & 1 & 34 & - & $\mathrm{S}$ & No & AWD 10 years \\
\hline \multirow[t]{4}{*}{ Harris NL (1984) [4] } & 2 & 49 & IEA & $\mathrm{S}$ & No & NED 14 years \\
\hline & 3 & 43 & IEA & S-ERT (30 Gy P) & No & NED \\
\hline & 4 & 50 & IEA & $\begin{array}{l}\text { S-ERT ( } 30 \text { Gy } \\
\text { P+18 Gy wall) }\end{array}$ & No & NED 3.3 years \\
\hline & 5 & 26 & IEA & $\mathrm{S}$ & No & NED 4 years \\
\hline Muntz HG (1991) [5] & 6 & 57 & IEA & $\begin{array}{l}\text { S-ERT (45 Gy } \\
\text { P + } 40 \text { Gy PA) }\end{array}$ & No & NED 4.5 years \\
\hline Stroh EL (1995) [6] & 7 & 62 & IIEA & $\begin{array}{l}\text { S-ERT-CT (30 Gy P+10 } \\
\text { Gy I)-(CHOP-Bleo) }\end{array}$ & No & NED 18 months \\
\hline Grace A (1999) [7] & 8 & 52 & IIIEA & Wait and watch & No & SD 4 months \\
\hline Vang R (2000) [3] & 9 & 61 & IIEA & S-ERT-CT & No & NED 6 years \\
\hline Bode MK (2002) [9] & 10 & 46 & IEA & $\begin{array}{l}\text { CT-RIT-ERT (3CEOP)- } \\
\text { (41.4 Gy P) }\end{array}$ & No & NED 10 months \\
\hline Baxter NP (2003) [8] & 11 & 75 & IVE & CT (Chlorambusil) & No & SD 6 months \\
\hline Present (2007) & 12 & 67 & IEA & $\begin{array}{l}\text { CT-ERT (3CHOP)- } \\
\text { (41.4 Gy P) }\end{array}$ & $\begin{array}{l}\text { (Nodal relapse at } \\
16 \text { months) RIT }\end{array}$ & NED 39 months \\
\hline
\end{tabular}

$C T$ Chemotherapy, ERT external radiotherapy, RIT rituximab, $S$ surgery, $N E D$ no evidence of disease, $S D$ stable disease, $A W D$ alive with disease, $P$ pelvis, $P A$ paraaortic, $I$ inguinal

month. As follow-up times were very short in some cases, complete evaluation of relapses was limited. All patients were alive. Eight patients had no evidence of disease, two had the stable disease, and one was alive with disease at the end of their follow up time.

Rituximab was the first monoclonal antibody, which has been registered for the treatment of B-cell lymphomas. The use of rituximab has been rapidly incorporated in clinical practice because of its significant clinical activity and few adverse effects [55]. Randomized studies have demonstrated its activity in untreated or relapsed cases of follicular lymphoma either as a single agent or in combination with chemotherapy [56-61]. Despite its widespread use, the optimal schedule for drug administration is still not completely defined.

Table 3 Lymphoma of the cervix treated with rituximab

\begin{tabular}{|c|c|c|c|c|c|c|}
\hline Author (year) & Number & Age & $\begin{array}{l}\text { Ann Arbor } \\
\text { stage }\end{array}$ & First-line treatment & Treatment of relapse & Survival \\
\hline Bode MK (2002) [9] & 1 & 46 & IEA & $\begin{array}{l}\text { CT-RIT-ERT (3CEOP)- } \\
(41.4 \text { Gy P) }\end{array}$ & No & $\begin{array}{l}\text { NED } \\
10 \text { months }\end{array}$ \\
\hline Kendrick JE (2005) [22] & 2 & 47 & IIE & $\begin{array}{l}\text { 4CHOP-RIT-ERT (50.4 } \\
\text { Gy P + } 9 \text { Gy boost) }\end{array}$ & No & $\begin{array}{l}\text { NED } \\
16 \text { months }\end{array}$ \\
\hline \multirow[t]{3}{*}{ Frey NV (2006) [17] } & 3 & 36 & IIE & $\begin{array}{l}\text { 3CHOP-RIT- } \\
\text { S-1CHOP-RIT }\end{array}$ & No & $\begin{array}{l}\text { NED } \\
36 \text { months }\end{array}$ \\
\hline & 4 & 56 & IIE & S-8CHOP-RIT & $\begin{array}{l}\text { Relapse in } \\
\text { retroperitoneum } \\
\text { at } 9 \text { months, } \\
\text { HDCT + ASCT }\end{array}$ & $\begin{array}{l}\text { NED } \\
15 \text { months }\end{array}$ \\
\hline & 5 & 49 & IIE & S-6CHOP-RIT & No & $\begin{array}{l}\text { NED } \\
32 \text { months }\end{array}$ \\
\hline \multirow[t]{2}{*}{ Cohn DE (2007) [18] } & 6 & 64 & IE & 5CHOP-RIT & No & $\begin{array}{l}\text { SD } \\
13 \text { months }\end{array}$ \\
\hline & 7 & 22 & IE & $\begin{array}{l}\text { 6CHOP-RIT-ERT } \\
(36 \text { Gy-P) }\end{array}$ & No & $\begin{array}{l}\text { NED } \\
14 \text { months }\end{array}$ \\
\hline Present (2007) & 8 & 67 & IEA & $\begin{array}{l}\text { CT-ERT (3CHOP)- } \\
(41.4 \text { Gy P) }\end{array}$ & $\begin{array}{l}\text { RIT (nodal relapse at } \\
16 \text { months) }\end{array}$ & $\begin{array}{l}\text { NED } \\
39 \text { months }\end{array}$ \\
\hline
\end{tabular}

$C T$ Chemotherapy, ERT external radiotherapy, RIT rituximab, $S$ surgery, $H D C T+A S C T$ high dose chemotherapy-autologous stem cell transplant, $N E D$ no evidence of disease, $S D$ stable disease, $P$ pelvis, $P A$ paraaortic 
There is less known about the primary cervix low-grade follicular lymphoma and a drug of rituximab and its effectiveness in the treatment of the primary disease and relapses. At first, Bode et al. [9] presented the patient with follicular lymphoma of the cervix who received three cycles CT combined with rituximab as a primary treatment (Table 3). After chemotherapy, the patient underwent radiotherapy with a total dose of $41.4 \mathrm{~Gy}$. Six months after the diagnosis, there was no residual tumor in the pelvis.

There also are 6 CD 20 B-cell primary cervix lymphomas treated with rituximab. All have taken rituximab combined with CHOP chemotherapy as a first-line therapy $[17,18,22]$. Only two of the six have been treated with ERT, and within the 14th and 16th months, no evidence of disease was noted. In one patient, rituximab combined with chemotherapy was used, while in three others, rituximab combined with chemotherapy were used postoperatively. Relapse has been developed at 9 months in one patient who has taken eight cycles of CHOP and rituximab postoperatively, but she was treated with high dose chemotherapy and autologous stem cell transplantation and had no disease at the sixth month of the transplantation [17].

In this report, we emphasized the dramatic response of a patient to the rituximab treatment after the relapse of primary cervix follicular lymphoma. Because of the bone marrow toxicity that occurred during the previous treatment, the patient being at an old age and refusing the multidrug chemotherapy regimen, only rituximab was used for treatment. The relapse regressed rapidly. The patient was diseasefree and in a good condition at the 39th month of diagnosis and at the 23rd month after the rituximab treatment.

As a conclusion, primary cervical low-grade follicular lymphoma is very rare disease. There is not an established treatment protocol for early stage diseases as well as relapses. Until the studies with larger series emerge, the results of case reports and study series with few patients inescapably gain importance. Systemic treatment modalities are considered to be effective in the treatment of relapse of primary cervix follicular lymphoma patients, while radiotherapy is considered to have a usage limited to palliation of life threatening symptoms only.

Although for the aged patients, who refuse the toxicities of combined systemic treatment, systemic rituximab monotherapy might be sufficient as an option with fewer side effects.

Acknowledgments This study was supported by the Akdeniz University Scientific Research Projects Unit.

\section{References}

1. Freeman C, Berg JW, Cutler SJ (1972) Occurrence and prognosis of extranodal lymphomas. Cancer 29(1):252-260
2. Charlton I, Karnei RF, King FM, Norris HJ (1974) Primary malignant reticulendothelial disease involving the vagina, cervix and corpus uteri. Obstet Gynecol 44:735-748

3. Vang R, Medeiros LJ, Ha CS, Deavers M (2000) Non-Hodgkin's lymphomas involving the uterus: a clinicopathologic analysis of 26 cases. Mod Pathol 13:19-28

4. Harris NL, Scully RE (1984) Malignant lymphoma and granulocytic sarcoma of the uterus and vagina. Cancer 53:2530-2545

5. Muntz HG, Ferry JA, Flynn D, Fuller AF Jr, Tarraza HM (1991) Stage IE primary malignant lymphomas of the uterine cervix. Cancer 68(9):2023-2032

6. Stroh EL, Besa PC, Cox JD, Fuller LM, Cabanillas FF (1995) Treatment of patients with lymphomas of the uterus or cervix with combination chemotherapy and radiation therapy. Cancer 75:2392-2399

7. Grace A, O'Connell N, Byrne P, Prendiville W, O'Donnell R, Royston D, Walsh CB, Leader M, Kay E (1999) Malignant lymphoma of the cervix. An unusual presentation and a rare disease. Eur J Gynaecol Oncol 20(1):26-28

8. Baxter NP, Lane G, Swift S (2003) Primary malignant follicular lymphoma of the cervix: a rare cause of postmenopausal bleeding. BJOG 110(3):337-338

9. Bode MK, Tikkakoski T, Johansson J, Johansson K, Kariniemi J, Apaja-Sarkkinen M, Tuominen H (2002) Lymphoma of the cervix. Acta Radiol 43(4):431-432

10. Hariprasad R, Kumar L, Bhatla N, Kukreja M, Papaiah S (2006) Primary uterine lymphoma: report of 2 cases and review of literature. Am J Obst Gynecol 195:308-313

11. Lee KM, Seah ES, Sethi VK (1998) Primary non-Hodgkin's lymphoma of the uterine cervix: case report of long-term survival of two patients treated with surgery and radiotherapy. Austral Radiol 42:126-127

12. Van Renterghem N, De Paepe P, Van den Broecke R, Bourgain C, Serreyn R (2005) Primary lymphoma of the cervix uteri: a diagnostic challenge. Report of two cases and review of the literature. Eur J Gynaecol Oncol 26(1):36-38

13. Thyagarajan MS, Dobson MJ, Biswas A (2004) Appearance of uterine cervical lymphoma on MRI: a case report and review of the literature. Br J Radiol 77:512-515

14. Kuo HC, Chou CY, Chang CH, Liu MT, Tzeng CC, Huang KE (1994) Primary malignant lymphoma of the uterine cervix shows favorable response to neoadjuvant chemotherapy. Gynecol Oncol 52(3):408-410

15. Szantho A, Balega JJ, Csapo Z, Sreter LL, Matolcsy A, Papp Z (2003) Primary non-Hodgkin's lymphoma of the uterine cervix successfully treated by neoadjuvant chemotherapy: case report. Gynecol Oncol 89(1):171-174

16. Perren T, Farrant M, McCarthy K, Harper P, Wiltshaw E (1992) Lymphomas of the cervix and upper vagina: a report of five cases and a review of the literature. Gynecol Oncol 44(1):87-95

17. Frey NV, Svoboda J, Andreadis C, Tsai DE, Schuster SJ, Elstrom R, Rubin SC, Nasta SD (2006) Primary lymphomas of the cervix and uterus: the University of Pennsylvania's experience and a review of the literature. Leuk Lymphoma 47(9):1894-1901

18. Cohn DE, Resnick KE, Eaton LA, deHart J, Zanagnolo V (2007) Non-Hodgkin's lymphoma mimicking gynecological malignancies of the vagina and cervix: a report of four cases. Int J Gynecol Cancer 17(1):274-279

19. Vang R, Medeiros LJ, Fuller GN, Sarris AH, Deavers M (2001) Non-Hodgkin's lymphoma involving the gynecologic tract: a review of 88 cases. Adv Anat Pathol 8:200-217

20. Montoto S, Lopez-Guillermo A, Altes A, Perea G, Ferrer A, Camos M, Villela L, Bosch F, Esteve J, Cervantes F, Blade J, Nomdedeu B, Campo E, Sierra J, Montserrat E (2004) Predictive value of Follicular Lymphoma International Prognostic Index (FLIPI) in patients with follicular lymphoma at first progression. Ann Oncol 15(10):1484-1489 
21. Pham DC, Guthrie TH, Ndubisi B (2003) HIV-associated primary cervical non-Hodgkin's lymphoma and two other cases of primary pelvic non-Hodgkin's lymphoma. Gynecol Oncol 90(1):204-206

22. Kendrick JE 4th, Straughn JM Jr (2005) Two cases of nonHodgkin's lymphoma presenting as primary gynecologic malignancies. Gynecol Oncol 98(3):490-492

23. Carbone PP, Kaplan HS, Musshoff K, Smithers DW, Tubiana M (1971) Report of the Committee on Hodgkin's Disease Staging Classification. Cancer Res 31(11):1860-1861

24. Jaffe ES, Harris NL, Stein H, Vardiman JW (eds) (2001) World Health Organization Classification of Tumours. Pathology and genetics of tumours of haematopoietic and lymphoid tissues. IARC, Lyon, pp 162-167

25. Aozasa K, Saeki K, Ohsawa M, Horiuchi K, Mishima K, Tsujimoto M (1993) Malignant lymphoma of the uterus. Report of seven cases with immunohistochemical study. Cancer 72(6):1959-1964

26. Trenhaile TR, Killackey MA (2001) Primary pelvic non-Hodgkin's lymphoma. Obstet Gynecol 97(5):717-720

27. Makarewicz R, Kuzminska A (1995) Non-Hodgkin's lymphoma of the uterine cervix: a report of three patients. Clin Oncol (R Coll Radiol) 7(3):198-199

28. Komaki R, Cox JD, Hansen RM, Gunn WG, Greenberg M (1984) Malignant lymphoma of the uterine cervix. Cancer 54(8):1699-1704

29. Awwad JT, Khalil AM, Shamseddine AI, Mufarrij AA (1994) Primary malignant lymphoma of the uterine cervix: is radiotherapy the best therapeutic choice for stage IE? Gynecol Oncol 52(1): 91-93

30. Tunca JC, Reddi PR, Shah SH, Slack ST (1979) Malignant nonHodgkin's-type lymphoma of the cervix uteri occurring during pregnancy. Gynecol Oncol 7:385-393

31. Yokoyama Y,Sato S, Xiao YH, Tanaka K, Maruyama H, Saito Y (2001) Primary non-Hodgkin's lymphoma of the uterine cervix. Arch Gynecol Obstet 265:108-111

32. Strang P, Sorbe B, Sundstrom C (1988) Primary aneuploid lymphoma of the uterine cervix: a case report. Gynecol Oncol 30(2):302-305

33. Khoury GG, Robinson A (1989) Lymphoma of uterine cervix. Eur J Surg Oncol 15(1):65-67

34. Heredia F, Bravo M, Pierotic M, Majlis A, Carmona L (2005) Neoadjuvant combined chemotherapy followed by external whole pelvic irradiation in two cases of primary extranodal nonHodgkin's lymphoma of the uterine cervix. Gynecol Oncol 97 (1):285-287

35. Fisher RI, Gaynor ER, Dahlberg S, Oken MM, Grogan TM, Mize EM, Glick JH, Coltman CA Jr, Miller TP (1993) Comparison of a standard regimen (CHOP) with three intensive chemotherapy regimens for advanced non-Hodgkin's lymphoma. N Engl J Med 328(14): 1002-1006

36. Chandy L, Kumar L, Dawar R (1998) Non-Hodgkin's lymphoma presenting as a primary lesion in uterine cervix: case report. J Obstet Gynaecol Res 24:183-187

37. Chan JK, Loizzi V, Magistris A, Hunter MI, Rutgers J, DiSaia PJ, Berman ML (2005) Clinicopathologic features of six cases of primary cervical lymphoma. Am J Obstet Gynecol 193(3 Pt 1):866-872

38. Castaldo TW, Ballon SC, Lagasse LD, Petrilli ES (1979) Reticuloendothelial neoplasia of the female genital tract. Obstet Gynecol 54(2):167-170

39. Papadopoulos AJ, Pambakian H, Devaja O, Raju KS (1996) High grade non-Hodgkin's stage IEB primary malignant lymphoma of the cervix and upper vagina. A case report. Eur J Gynaecol Oncol 17(6):484-486

40. Mansouri H, Kebdani T, Hassouni K, El Gueddari B (2001) Unusual locations for lymphomas. Case 1. Intermediate-grade lymphoma of the cervix. J Clin Oncol 19(11):2959-2960

41. Kahlifa M, Buckstein R, Perez-Ordonez B (2003) Sarcomatoid variant of B-cell lymphoma of the uterine cervix. Int $\mathrm{J}$ Gynecol Pathol 22(3):289-293
42. Cantu de Leon D, Perez Montiel D, Chanona Vilchis J (2006) Primary malignant lymphoma of uterine cervix. Int $\mathrm{J}$ Gynecol Cancer 16(2):923-927

43. Montoto S, Lopez-Guillermo A, Altes A, Perea G, Ferrer A, Camos M, Villela L, Bosch F, Esteve J, Cervantes F, Blade J, Nomdedeu B, Campo E, Sierra J, Montserrat E (2004) Predictive value of follicular lymphoma international prognostic index (FLIPI) in patients with follicular lymphoma at first progression. Ann Oncol 15(10): 1484-1489

44. Vaughan Hudson B, Vaughan Hudson G, MacLennan KA, Anderson L, Linch DC (1994) Clinical stage 1 non-Hodgkin's lymphoma: long-term follow-up of patients treated by the British National Lymphoma Investigation with radiotherapy alone as initial therapy. Br J Cancer 69(6):1088-1093

45. Kelsey SM, Newland AC, Hudson GV, Jelliffe AM (1994) A British National Lymphoma Investigation randomised trial of single agent chlorambucil plus radiotherapy versus radiotherapy alone in low grade, localised non-Hodgkin's lymphoma. Med Oncol 11(1):19-25

46. MacManus MP, Seymour JF (2001) Management of localized low-grade follicular lymphomas. Australas Radiol 45:326-334

47. Gospodarowicz MK, Bush RS, Brown TC, Chua T (1984) Prognostic factors in nodular lymphomas: a multivariate analysis based on the Princess Margaret Hospital experience. Int J Radiat Oncol Biol Phys 10:489-497

48. Czuczman MS, Weaver R, Alkuzweny B, Berlfein J, Grillo-Lopez AJ (2004) Prolonged clinical and molecular remission in patients with low-grade or follicular non-Hodgkin's lymphoma treated with rituximab plus CHOP chemotherapy: 9-year follow-up. J Clin Oncol 22:4711-4716

49. McLaughlin P, Fuller LM, Velasquez WS, Sullivan-Halley JA, Butler JJ, Cabanillas F (1986) Stage I-II follicular lymphoma. Treatment results for 76 patients. Cancer 58(8):1596-1602

50. Morel P, Dupriez B, Plantier-Colcher I, Gosselin B, Declercq C, Pollet JP, Bauters F (1993) Long-term outcome of follicular lowgrade lymphoma. A report of 91 patients. Ann Hematol 66 (6):303-308

51. Carde P, Burgers JM, van Glabbeke M, Hayat M, Cosset JM, Somers R, Sizoo W, Qasim MM, Lefur R, Abbatucci JS, et al. (1984) Combined radiotherapy-chemotherapy for early stages non-Hodgkin's lymphoma: the 1975-1980 EORTC controlled lymphoma trial. Radiother Oncol 2(4):301-312

52. Nissen NI, Ersboll J, Hansen HS, Walbom-Jorgensen S, PedersenBjergaard J, Hansen MM, Rygard J (1983) A randomized study of radiotherapy versus radiotherapy plus chemotherapy in stage I-II non-Hodgkin's lymphomas. Cancer 1;52(1):1-7

53. Yahalom J, Varsos G, Fuks Z, Myers J, Clarkson BD, Straus DJ (1993) Adjuvant cyclophosphamide, doxorubicin, vincristine, and prednisone chemotherapy after radiation therapy in stage I lowgrade and intermediate-grade non-Hodgkin lymphoma. Results of a prospective randomized study. Cancer 71(7):2342-2350

54. Seymour JF, Pro B, Fuller LM, Manning JT, Hagemeister FB, Romaguera J, Rodriguez MA, Ha CS, Smith TL, Ayala A, Hess M, Cox JD, Cabanillas F, McLaughlin P (2003) Long-term followup of a prospective study of combined modality therapy for stage I-II indolent non-Hodgkin's lymphoma. J Clin Oncol 21(11): 2115-2122

55. Boye J, Elter T, Engert A (2003) An overview of the current clinical use of anti-CD20 monoclonal antibody rituximab. Ann Oncol 14: $520-535$

56. McLaughlin P, Grillo-Lopez AJ, Link BK, Levy R, Czuczman MS, Williams ME, Heyman MR, Bence-Bruckler I, White CA, Cabanillas F, Jain V, Ho AD, Lister J, Wey K, Shen D, Dallaire BK (1998) Rituximab chimeric anti-CD20 monoclonal antibody therapy for relapsed indolent lymphoma: half of patients respond to a fourdose treatment program. J Clin Oncol 16(8):2825-2833 
57. Foran JM, Gupta RK, Cunningham D, Popescu RA, Goldstone AH, Sweetenham JW, Pettengell R, Johnson PW, Bessell E, Hancock B, Summers K, Hughes J, Rohatiner AZ, Lister TA (2000) A UK multicentre phase II study of Rituximab (chimaeric anti-CD20 monoclonal antibody) in patients with follicular lymphoma, with PCR monitoring of molecular response. $\mathrm{Br} \mathrm{J}$ Haematol 109(1):81-88

58. Colombat P, Salles G, Brousse N, Eftekhari P, Soubeyran P, Delwail V, Deconinck E, Haioun C, Foussard C, Sebban C, Stamatoullas A, Milpied N, Boue F, Taillan B, Lederlin P, Najman A, Thieblemont C, Montestruc F, Mathieu-Boue A, Benzohra A, Solal-Celigny P (2001) Rituximab (anti-CD20 monoclonal antibody) as single first-line therapy for patients with follicular lymphoma with a low tumor burden: clinical and molecular evaluation. Blood 97(1):101-106

59. Igarashi T, Kobayashi Y, Ogura M, Kinoshita T, Ohtsu T, Sasaki Y, Morishima Y, Murate T, Kasai M, Uike N, Taniwaki M, Kano Y, Ohnishi K, Matsuno Y, Nakamura S, Mori S, Ohashi Y, Tobinai K (2002) IDEC-C2B8 Study Group in Japan. Factors affecting toxicity, response and progression-free survival in relapsed patients with indolent B-cell lymphoma and mantle cell lymphoma treated with rituximab: a Japanese phase II study. Ann Oncol 13(6):928-943

60. Forstpointner R, Dreyling M, Repp R, Hermann S, Hanel A, Metzner B, Pott C, Hartmann F, Rothmann F, Rohrberg R, Bock HP, Wandt H, Unterhalt M, Hiddemann W, German Low-Grade Lymphoma Study Group (2004) The addition of rituximab to a combination of fludarabine, cyclophosphamide, mitoxantrone (FCM) significantly increases the response rate and prolongs survival as compared with FCM alone in patients with relapsed and refractory follicular and mantle cell lymphomas: results of a prospective randomized study of the German Low-Grade Lymphoma Study Group. Blood 104(10):3064-3071

61. Czuczman MS, Koryzna A, Mohr A, Stewart C, Donohue K, Blumenson L, Bernstein ZP, McCarthy P, Alam A, HernandezIlizaliturri F, Skipper M, Brown K, Chanan-Khan A, Klippenstein D, Loud P, Rock MK, Benyunes M, Grillo-Lopez A, Bernstein SH (2005) Rituximab in combination with fludarabine chemotherapy in low-grade or follicular lymphoma. J Clin Oncol 23(4):694-704 